Marcin Komańda

\title{
Zarys problemu wykorzystania internetu w badaniach jakościowych
}

Oryginalnie opublikowane w: „Przegląd Organizacji” 12/2010, s. 36- 39 (ISSN 0137-7221)

\section{Wprowadzenie}

W nauce o zarządzaniu coraz częściej można spotkać się z przeprowadzanymi badaniami jakościowymi. Wynika to $\mathrm{z}$ obecnej popularności podejścia sytuacyjnego do badanej rzeczywistości, które zakłada szczególność określonego i wybranego układu sił/zjawisk poddawanego analizie [GOLAFSHANI 2003]. Pozyskane dane jakościowe są w tym kontekście uznawane za cenne, gdyż są ściśle związane z wybranym problemem badawczym, a także dostarczają jego bogaty opis. Pozwalają one także na możliwość wyjaśnienia pojedynczych zdarzeń, a także ich ciągu w zakreślonym obszarze zainteresowań badacza [MILES, HUBERMAN 2000]. O ile twierdzi się, że badania jakościowe w stosunku do badań ilościowych cechują się mniejszą standaryzacją procedur ich przeprowadzania, to jednocześnie podkreśla się, że mogą one dzięki temu doprowadzić do zaskakującej integracji wiedzy. Ta cecha sprawia, że badania jakościowe są wykorzystywane przy próbach opisu nowo zakreślonych problemów badawczych [KONECKI 2000]. Wśród potencjalnych słabych stron badań jakościowych związanych z konkretnymi metodami wymienia się natomiast przede wszystkim kwestie związane z doborem przypadków, gromadzeniem danych, a także zagadnienia związane z poddawaniem ich analizie i wysuwaniu na ich podstawie generalizacji [MILES 1979]. Współcześnie zarysowuje się również szereg problemów związanych z przeprowadzaniem tych badań w oparciu o wirtualne środowisko, jakim jest internet. Artykuł ten podejmuje próbę odpowiedzi na pytanie, jak należy rozpatrywać owe wirtualne środowisko oraz stara się określić wyzwania związane $\mathrm{z}$ realizacją zadań badawczych $\mathrm{w}$ internecie.

\section{Internet a dane jakościowe}

Problem analizy danych jakościowych potęguje się w przypadku, gdy badacz nie rozumie rzeczywistej istoty kontekstu pozyskanych danych. Współczesne szerokie 
wykorzystanie narzędzi informatycznych, a w szczególności internetu sprawia, że środowisko wirtualne staje się istotnym, aczkolwiek niekoniecznie prawidłowo rozumianym tłem zgromadzonych danych rzutującym na ich interpretację. W literaturze przedmiotu przyjmuje się, że kontekst elektronicznego środowiska (internetu) można spostrzegać na trzy sposoby: jako narzędzia, miejsca i sposobu bycia. Przytaczane tu odniesienie się do internetu w swoim klasycznym ujęciu jest przedstawiane jako trzy możliwe i odrębne punkty wiedzenia [MARKHAM 2004]. Jednak należy zwrócić uwagę, że można przyjąć ich wzajemne uwarunkowanie i tak zostaną one zaprezentowane w niniejszym artykule.

W przypadku rozumienia internetu jako „narzędzia” przyjmuje się, że jest on sposobem na przekazywanie informacji, nawiązywania interakcji w procesie komunikowania się z innymi uczestnikami sieci, czy też sposobem na prowadzenie symultanicznej pracy. Wskazuje się często w tym zawężonym kontekście na korzyści, jakie to „narzędzie” może wraz z jego użytkowaniem przynieść (na przykład obniżka kosztów działania, przyspieszenie pracy, niezależność od fizycznego miejsca przebywania poszczególnych kooperantów). W przypadku „miejsca” internet należy rozumieć jako przestrzeń, w której realizują się interakcje pomiędzy podmiotami. Integralną częścią tej przestrzeni jest architektura powiązań określona przez narzędzia wykorzystywane w komunikowaniu się, jednak ona sama jest związana również ze sposobami wykorzystania tychże narzędzi w konkretnych przypadkach, w konkretnych celach, jak i ze zmiennością przebiegu owych interakcji w czasie (niekoniecznie pokrywających się z przeznaczeniem stosowanych „narzędzi”). Nie można zatem zapomnieć, że „miejsce” owo związane jest z szeroko rozumianym kontekstem społeczno-kulturowym. Sposób bycia wskazuje z kolei na problem samo określania się użytkowników internetu. To „miejsce” pozwala na to, by mogli oni występować jako ktokolwiek - nie ma znaczenia płeć, wykształcenie, zainteresowania, poglądy polityczne, miejsce pochodzenia, status społeczny. Każdy może stać się tym, kim chce w pożądanych przez niego celach, a więc wykorzystać we właściwy w sobie sposób i we właściwym sobie celu określone „miejsce” i „narzędzia” [MARKHAM 2004]. Można przyjąć zatem, iż pierwsze podejście akcentuje relacje formalne pomiędzy uczestnikami środowiska wirtualnego, drugie poszerza analizę o relacje nieformalne, a trzecie prowadzi do zredefiniowania przeznaczenia i wykorzystania ustalonej architektury powiązań.

Wybór określonego rozumienia internetu jako badawczego kontekstu jest niezbędny dla prawidłowości przeprowadzenia badań jakościowych. Jednocześnie badacz spotyka się ze szczególnymi zagrożeniami wynikającymi z takiego, a nie innego odniesienia się do zebranych danych (patrz tabela 1). Są one powiązane $z$ głównymi zagrożeniami 
wynikającymi przy realizacji badań jakościowych, a wśród których można wyróżnić: praco- i czasochłonność gromadzenia i analizy zebranych danych; przeładowanie zebranymi danymi, które niekoniecznie będą dotyczyć badanego zjawiska; brak znajomości uwarunkowań i procedury przeprowadzonych badań [MILES 1979], co może rzutować na stopień prawdziwości uogólnień wyciąganych z zebranych danych [CZAKON 2006]. Znajomość procedury wybranej metody badań jakościowych jest warunkiem podstawowym, dlatego też nie zostanie on uwzględniony w prezentowanej tabeli. Można jednak zwrócić uwagę, że istotną kwestią $\mathrm{w}$ tym zakresie stanie się rozstrzygnięcie, czy wykorzystana zostanie procedura standardowa, czy też zostanie ona określona na potrzeby danego badania (w takim przypadku mogą pojawić się dodatkowe problemy, które będą musiały zostać rozwiązane na bieżąco w trakcie realizacji procedury badawczej).

Tab. 1. Główne zagrożenia wynikające z badań jakościowych a rozumienie internetu

\begin{tabular}{|c|c|c|c|}
\hline \multirow{2}{*}{$\begin{array}{c}\text { Zagrożenia } \\
\text { wynikające z badań } \\
\text { jakościowych }\end{array}$} & \multicolumn{3}{|c|}{ Rozumienie internetu } \\
\hline & Narzędzie & Miejsce & Sposób bycia \\
\hline $\begin{array}{l}\text { Praco- i } \\
\text { czasochłonność }\end{array}$ & $\begin{array}{c}\text { Konieczność określenia } \\
\text { stosowanych narzędzi } \\
\text { komunikacji } \\
\text { (wszystkich/większości, } \\
\text { czy najbardziej istotnych } \\
\text { z punktu widzenia } \\
\text { przyjętego problemu } \\
\text { badawczego?) }\end{array}$ & $\begin{array}{l}\text { Dynamika architektury } \\
\text { powiązań pomiędzy } \\
\text { podmiotami (możliwość } \\
\text { braku jej prawidłowego } \\
\text { określenia) }\end{array}$ & $\begin{array}{c}\text { Konieczność } \\
\text { zidentyfikowania } \\
\text { zachowań i poglądów } \\
\text { użytkowników sieci w } \\
\text { dłuższym horyzoncie } \\
\text { czasowym }\end{array}$ \\
\hline $\begin{array}{l}\text { Przeładowanie } \\
\text { danymi }\end{array}$ & $\begin{array}{l}\text { Zebranie wielu danych o } \\
\text { charakterze czysto } \\
\text { technicznym (być może } \\
\text { nie istotnych z punktu } \\
\text { widzenia założonego } \\
\text { problemu badawczego) }\end{array}$ & $\begin{array}{l}\text { Konieczność odniesienia } \\
\text { się do „narzędzi” i } \\
\text { kontekstu społecznego } \\
\text { kulturowego (jak szeroko } \\
\text { je analizować?) }\end{array}$ & $\begin{array}{l}\text { Konieczność śledzenia } \\
\text { różnorakich aktywności } \\
\text { internautów }\end{array}$ \\
\hline $\begin{array}{l}\text { Brak znajomości } \\
\text { uwarunkowań } \\
\text { przeprowadzonych } \\
\text { badań }\end{array}$ & $\begin{array}{c}\text { Nieograniczenie się } \\
\text { jedynie do „narzędzi”, ale } \\
\text { również analizowanie } \\
\text { „miejsca” }\end{array}$ & $\begin{array}{l}\text { Pominięcie kontekstu } \\
\text { kulturowego, brak } \\
\text { odniesienia się wobec } \\
\text { powiązań między } \\
\text { podmiotami }\end{array}$ & $\begin{array}{c}\text { Problem stopnia } \\
\text { pewności analizy } \\
\text { zachowań podmiotów }\end{array}$ \\
\hline
\end{tabular}

Źródło: opracowanie własne.

W przypadku problemu pracochłonności i czasochłonności przeprowadzanych badań jakościowych należy zwrócić uwagę, że w zależności od przyjętego sposobu patrzenia na problem internetu, wzrasta poziom złożoności analizy (patrz rysunek). „Narzędzie”wymaga zidentyfikowania stosowanych rozwiązań w zakresie komunikowania się i określenia ich 
przeznaczenia. W przypadku „miejsca” dochodzi do tego również przydatność i częstotliwość ich wykorzystywania w konkretnych przypadkach przez konkretne osoby. W „sposobie bycia" natomiast należy dodatkowo jeszcze dokonać analizy, czy użytkownicy sieci (a więc i konkretnych narzędzi) prezentują spójne i trwałe zachowanie

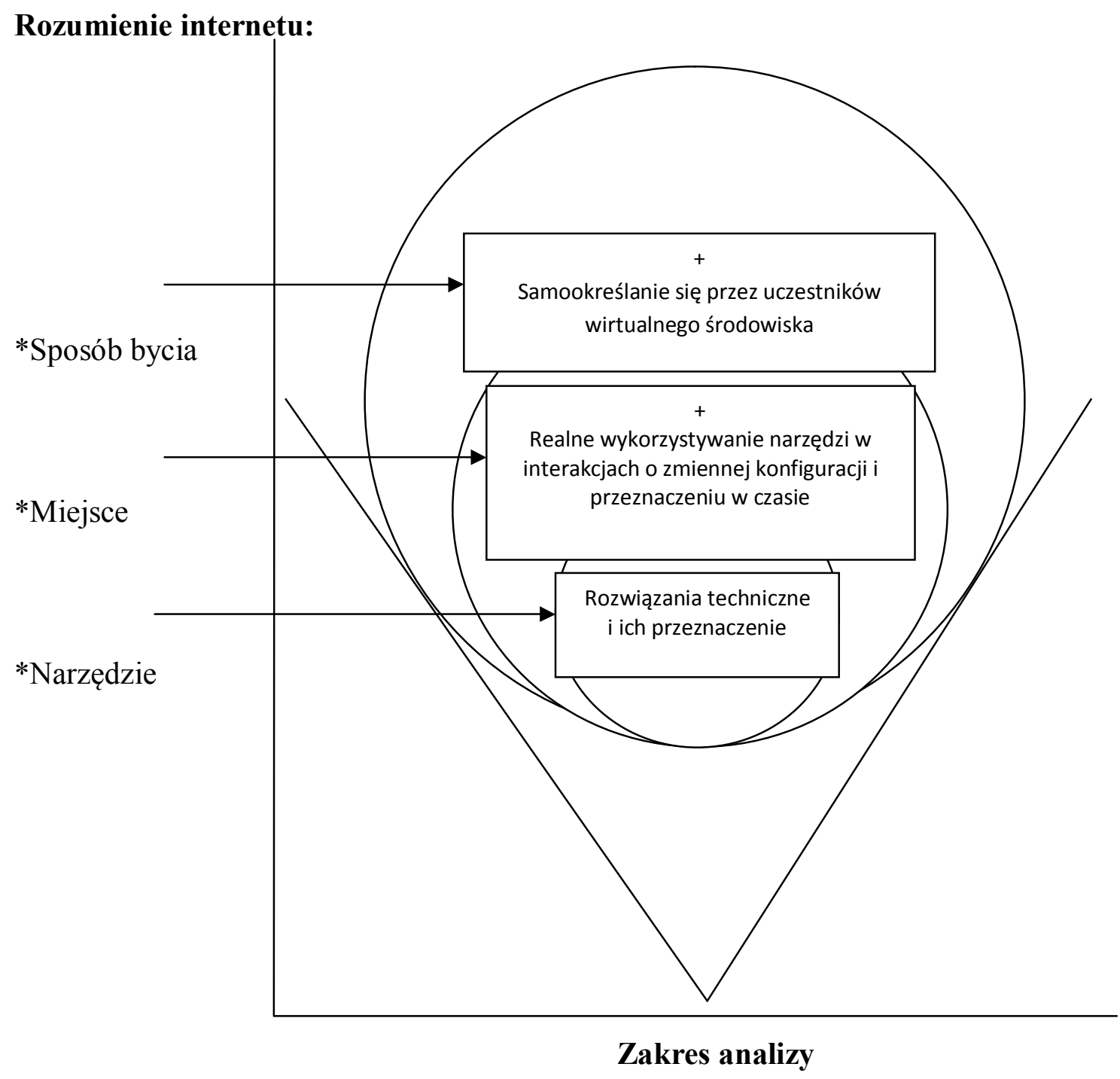

Rys. Poziom złożoności analizy danych jakościowych w zależności od rozumienia ich wirtualnego kontekstu

Źródło: opracowanie własne na podstawie A.N. MARKHAM, Internet Communication as a Tool for Qualitative Research, [w:] Qualitative Research. Theory, Method and Practice, Silverman D. (red.), SAGE Publications, London, Thousand Oaks, New Delhi, 2004, s. 98100

i czy w związku z tym, rzeczywiście można przyjąć, że są tymi, za kogo się podają. To ustalenie z kolei jest kluczowe dla stopnia pewności wyciąganych uogólnień na podstawie 
analizy zebranych danych. W przypadku „miejsca” ważne w tym kontekście staje się odniesienie do uwarunkowań kulturowych i społecznych rzutujących na charakter interakcji, jak i prawidłowy ich przebieg [HULTEN, BJOERKSTRAND 2009]. Istotny aspekt stanowi natomiast problem błędnego zrozumienia kontekstu internetu $\mathrm{w}$ przypadku przyjęcia odniesienia się do środowiska wirtualnego jako „narzędzia”. Może to skutkować tym, że będzie się o wiele szerzej analizować je niż się powinno (w szczególności może dojść tu do odniesienia się do internetu jako „miejsca”). Przeładowanie danymi wiąże się z kolei z tym, że pozyskane zostaną niekoniecznie dane o charakterze istotnym dla badanego problemu. W przypadku rozumienia internetu jako „narzędzia” może nastąpić koncentracja na specyfikacjach technicznych bez należytego odniesienia się do przeznaczenia konkretnych rozwiązań [BULEARCA, BULEARCA 2009]. W odniesieniu do „miejsca” należy dokonać również analizy narzędzi, ale trzeba wyraźnie określić co jest celem przeprowadzanych badań w tym przyjętym odniesieniu się do internetu, aby nie analizować danych o charakterze technicznym niemających wpływu na badany problem. W „sposobie bycia” istnieje konieczność względnego potwierdzenia dokonanych spostrzeżeń, co pozwoli przedsięwziąć w konsekwencji dalsze kroki w analizie pozyskanych danych jakościowych.

\section{Wybrane problemy badań jakościowych w Internecie: forum dyskusyjne}

Fora internetowe są specyficznym obiektem zainteresowań. Samo forum skupia internautów zaintrygowanych wybranym tematem/problemem, jednak może ono być założone specjalnie dla potrzeb dyskusyjnych danej grupy lub być utworzone w ramach już jakieś istniejącej strony internetowej, która w takim przypadku będzie skupiać różne fora tematyczne. W tym drugim przypadku istotny będzie też fakt, że użytkownicy prawdopodobnie będą udzielać się na kilku lub wszystkich podforach.

Fora internetowe są istotnym źródłem informacji, które można wykorzystać w badaniach. Przede wszystkim oferują one możliwość poznania opinii i sądów internautów na dany temat. Użytkownicy forum wykorzystują dostępne im narzędzia informatyczne by wyrażać swoje zdanie, co dodatkowo daje możliwość badaczowi zrozumienia ich intencji i rzeczywistych przekonań. Można tu wspomnieć o wykorzystywaniu cytowań, podawania oraz linków, prezentowania maili, wstawiania materiałów filmowych, czy też zdjęć [EYSENBACH, JAMES 2001].

Główny problem $\mathrm{z}$ interpretacją informacji zawartych $\mathrm{w}$ forach dyskusyjnych związany jest przede wszystkim ze zrozumieniem rzeczywistych celów leżących u podstaw 
ich działalności na forum, a związku z tym, czy osoby które występują na forum w danej roli, rzeczywiście są tymi, za kogo się podają. Przykładami obrazującymi ten problem mogą być fora poświęcone ocenie przez klientów produktów firmy, czy też świadczonych usług. Należy rozstrzygnąć, kto tak naprawdę umieszcza na forum swoje opinie. Czy są to rzeczywiście klienci, czy konkurencja (w przypadku negatywnych opinii), a może i przedstawiciele samej firmy (w przypadku pozytywnych opinii). Przy analizie informacji w takim przypadku należy wziąć pod uwagę następujące czynniki: ilość wygłoszonych opinii, czas w jakim były one zgłaszane (na przykład nagromadzenie negatywnych opinii w krótkim czasie może świadczyć o akcji negatywnego PRu przeprowadzonego przez konkurencję), czy też zwrócić uwagę na dane użytkowników (np. adres IP). Działanie te podejmowane przez badacza mają mieć na celu odróżnienie istotnych i rzetelnych danych od pozostałych, jakie można znaleźć na forum.

Tab. 2. Źródła informacji pochodzących $\mathrm{z}$ forum internetowego i zagrożenia dla ich interpretacji

\begin{tabular}{|l|l|}
\hline Źródła informacji & $\begin{array}{l}\text { Komentarze użytkowników forum, zamieszczone zdjęcia, } \\
\text { filmy, linki (odnośniki) do innych stron, cytowanie, } \\
\text { zamieszczona korespondencja elektroniczna }\end{array}$ \\
\hline Zagrożenie dla interpretacji & $\begin{array}{l}\text { Brak pewności co do roli odgrywanej przez poszczególnych } \\
\text { użytkowników forum, a co za tym idzie, brak pewności co do } \\
\text { informacji }\end{array}$ \\
\hline
\end{tabular}

Źródło: opracowanie własne

Podejmowanie badań jakościowych opartych o wykorzystanie informacji pochodzących $\mathrm{z}$ internetu, a $\mathrm{w}$ szczególności $\mathrm{z}$ forum dyskusyjnego, wiąże się również $\mathrm{z}$ określonymi problemami etycznymi, z jakimi musi się badacz zmierzyć. Główny problem, który musi zostać rozwiązany polega na wyborze formy przeprowadzanego badania, a co za tym idzie, czy zostanie ono przeprowadzone w sposób aktywny, czy też pasywny. Badacz musi określić, czy wystarczy mu obserwacja zasobów strony internetowej (forum), czy też włączy się w aktywność wykazywaną przez użytkowników strony. Z jednej strony włączenie się w działalność internautów może pomóc w poznaniu ich rzeczywistych intencji, z drugiej strony aktywność badacza może doprowadzić do zmiany zachowań grupy już udzielającej się. Ewentualny wybór formy badania zależeć będzie również od tego, czy będzie się miało do czynienia z grupą zamkniętą, czy też otwartą (a także czy zasoby forum/strony będą upublicznione, czy też nie); od bieżącej ilości uczestników badanej grupy, czy też norm jakimi będą się oni wykazywać w swojej aktywności. Powyższe kwestie przekładają się z kolei na dalsze problemy, które związane są z ewentualną koniecznością zachowania 
prywatności użytkowników strony/forum. Potencjalne zidentyfikowanie forumowiczów lub wykorzystanie informacji podawanych przez nich może doprowadzić do zaszkodzenia im w realnym świecie. Pozostaje również do rozważenia problematyka własności intelektualnej, związanej z tym, czy badacz może wykorzystywać wszystkie informacje, jakie zostają podane na forum/stronie internetowej przez jej użytkowników i czy ewentualna możliwość odniesienia się do nich zależy jedynie od celów badania. Na gruncie tych wątpliwości wysuwa się zatem czasem postulat konieczności uzyskania zgody od użytkowników, względnie właściciela forum na przeprowadzenie badań [BOWEN 2005]. W ten sposób autorzy opracowań literaturowych w tym temacie w sposób pośredni odnoszą się ponownie do problemu wpływu na zawartość strony/forum, jak i zachowań jej/jego użytkowników. Realizacja badań jakościowych w internecie przekłada się więc na ogólny dylemat, czy dążyć do poszukiwania prawdy za wszelką cenę, czy postępować przede wszystkim ze wszechmiar uczciwie wobec innych użytkowników sieci.

\section{Zakończenie}

Przeprowadzenie badań jakościowych w Internecie wymaga od badacza przede wszystkim określenia sposobu odniesienia się do istoty wirtualnej rzeczywistości szczególnie w momencie interpretacji danych, a także na wyborze określonej metody badawczej. Przy realizacji badań należy spodziewać się, iż z jednej strony zebrany materiał będzie bogaty, z drugiej strony jednak będą istniały poważne zastrzeżenia co do jego wartości.

Jednoczesne dążenie do pozyskania względnie pewnego i rzetelnego materiału do badań naraża badacza na działania z pogranicza zachowań nieetycznych. Bezpośrednie zaangażowanie w działalność forum internetowego polegające na prowokowaniu określonych zachowań przez użytkowników forum będących nieświadomymi roli, jaką wypełnia badacz, może wydawać się za nieusprawiedliwione. Relacje pomiędzy określoną, przyjętą rolą badacza a rolami użytkowników internetu stanowią i będą stanowić źródło dylematów natury etycznej.

Złożoność kwestii związanych z pozyskiwaniem i oceną informacji pozyskiwanych ze środowiska wirtualnego, jakim jest internet sprawia, że problemy te będą jeszcze długo dyskutowane. Należy jednak raczej spodziewać się, że w kontekście gwałtownej dynamiki wykorzystania dostępnych rozwiązań komunikacyjnych, jak i przebiegu relacji pomiędzy internautami w czasie i w przestrzeni, prawdopodobnie wypracowane zostaną co najwyżej pewne ogólne zasady/wytyczne postępowania przy realizacji owych badań i interpretacji danych z nich pochodzących. 


\section{Bibliografia}

BOWEN G.A., Preparing a Qualitative Research-Based Dissertation: Lessons Learned, „, The Qualitative Report” 2/2005

BULEARCA M., BULEARCA S., Internet and Interactive Websites: Cornerstones of Competitive Advantage in the Virtual Economy, „Global Business and Management Research: an International Journal” 3/4/2009

CZAKON W., Łabędzie Poppera - case studies w badaniach nauk o zarządzaniu, „Przegląd Organizacji" 9/2006

EYSENBACH G., JAMES E.T., Ethical Issues in Qualitative Research on Internet Communities, „British Medical Journal” 323/2001

GOLAFSHANI N., Understanding Reliability and Validity in Qualitative Research, ,The Qualitative Report" 4/2003

HULTEN P., BJOERKSTRAND H., A Case Study of the Development of an E-service for the Swedish Mining Industry, ,Services Marketing Quarterly” 30/2009

KONECKI K., Studia $z$ metodologii badań jakościowych. Teoria ugruntowana, Wydawnictwo Naukowe PWN, Warszawa 2000, s. 101

MARKHAM A.N., Internet Communication as a Tool for Qualitative Research, [w:] Qualitative Research. Theory, Method and Practice, Silverman D. (red.), SAGE Publications, London, Thousand Oaks, New Delhi, 2004, s. 98-100

MILES M.B., Qualitative Data as an Attractive Nuisance: the Problem of Analysis, „Administrative Science Quarterly”, Vol. 24, 1979

MILES M.B., HUBERMAN A.M., Analiza danych jakościowych, Trans Humana Wydawnictwo Uniwersyteckie, Białystok 2000, s. 1

\section{Summary}

Virtual environment, which is the internet, is often conducted in the context of qualitative research. This act raises certain problems with the acquisition and interpretation of data. It is therefore important to a proper understanding of the substance of the Internet, particularly in relation to the use of technological solutions and the activity of its users. Conducting qualitative research in a virtual environment involves a number of challenges about ethic issues which should be solved in the stage of study planning. 


\section{Streszczenie}

Środowisko wirtualne, jakim jest internet, staje się często kontekstem w prowadzonych badaniach jakościowych. Rodzi to określone problemy z pozyskiwaniem i interpretacją danych. Ważne zatem jest właściwe zrozumienie istoty internetu, szczególnie w odniesieniu do stosowanych rozwiązań technologicznych oraz aktywności jego użytkowników. Przeprowadzenie badań jakościowych w środowisku wirtualnym pociąga za sobą również szereg wyzwań o naturze etycznej, które muszą w dużej mierze zostać rozstrzygnięte już przy planowaniu badania. 